\title{
PERANAN PERMAINAN TRADISIONAL ENGKLEK DALAM MENGEMBANGKAN KETERAMPILAN SOSIAL ANAK USIA SEKOLAH DASAR DI DESA HAMPARAN PERAK
}

\author{
Wiwik Lestari , Nurdiana Siregar
}

Surel: lestariwiwik201180@yahoo.co.id

\begin{abstract}
ABSTRACK
This study aims to describe the traditional game played hopscotch elementary school children in the Hamparan Perak village. This study used a qualitative approach. The subjects were children of primary school age who live in the Hamparan Perak village. Data was collected by observation, interview, and documentation. The results of this study indicate that the traditional hopscotch game in Hamparan Perak village there are three forms of the scarecrow, box, and aircraft. Game hopscotch jump performed by each of the rectangular pattern is drawn with one leg bent and the foot is lifted. All four terms that have been bypassed by gacok, players have the opportunity to embellish the house in one of the boxes, by throwing gacok to one rectangle with the backs of hopscotch. Players who earn the most home wins stamp.
\end{abstract}

Keywords : traditional games, social skills

\begin{abstract}
ABSTRAK
Penelitian ini bertujuan untuk mendeskripsikan permainan tradisional engklek yang dimainkan anak usia Sekolah Dasar (SD) di Desa Hamparan Perak. Penelitian ini menggunakan pendekatan kualitatif. Subjek penelitian ini adalah anak usia SD yang berdomisili di Desa Hamparan Perak. Teknik pengumpulan data dilakukan dengan observasi, wawancara, dan dokumentasi. Hasil penelitian ini menunjukkan bahwa Permainan tradisional engklek di desa Hamparan Perak ada tiga bentuk yaitu orang-orangan, kotak, dan pesawat. Permainan engklek dilakukan dengan melompati setiap segi empat dari pola yang digambar dengan satu kaki dan menekuk kaki yang diangkat. Semua segi empat yang sudah dilewati oleh gacok, pemain berkesempatan untuk membubuhi rumah di salah satu kotak, dengan cara melempar gacok melewati kepala pemain ke salah satu segi empat dengan cara membelakangi pola engklek. Pemain yang memperoleh paling banyak bubuhan rumah itulah pemenangnya.
\end{abstract}

Kata Kunci : permainan tradisional, keterampilan sosial

\section{PENDAHULUAN}

Bermain merupakan suatu hal yang menyenangkan bagi anak usia Sekolah Dasar (SD). MZW (2017:14) menjelaskan bahwa bermain merupakan kebutuhan primer bagi anak. Sejalan dengan Montolalu, dkk (2008:1.2) bermain merupakan kebutuhan anak.
Anak bermain dengan memainkan permainan tradisional dan permainan elektronik. Anak usia Sekolah Dasar (SD) di era digital ini, banyak menghabiskan waktunya dengan bermain game online di internet, gadged, playstation dan game di telepon genggam. Hal tersebut dapat mengakibatkan siswa 
tidak memainkan permainan tradisional di lapangan. Seperti yang dijelaskan oleh MZW (2017:14) salah satu faktor yang menyebabkan anak kurang beraktivitas dan bermain adalah teknologi. Iswinarti (Tim Playpus Indonesia, 2017) menyatakan bahwa permainan menggunakan teknologi digital dapat menimbulkan agresitivitas dan kompetensi sosial yang rendah.Oleh karena itu, Iswinarti (Tim Playpus Indonesia, 2017) menyatakan bahwa alternatif pendidikan untuk mengoptimalkan perkembangan anak yaitu melalui menerapkan kembali permainan tradisional.

Permaian tradisional adalah permainan yang tidak menggunakan alat dan menggunakan alat sederhana serta merupakan tradisi atau permainan yang sudah dimainkan dari generasi ke generasi. Prawitasari (2016:266) menjelaskan bahwa permainan tradisional memiliki nilainilai luhur diantaranya kerjasama, sikap toleransi, sikap empati, dan menghilangkan keegoisan pribadi. Dapat dinyatakan bahwa permainan tradisional dapat mengembangkan keterampilan sosial anak.

Keterampilan sosial adalah kemampuan anak untuk berhubungan baik dan harmonis dengan orang disekitarnya. Adapun indikator yang menunjukkan anak memiliki keterampilan sosial adalah : 1) keterampilan dalam bekerjasama, 2) keterampilan dalam menyesuaikan diri, 3) keterampilan dalam berinteraksi, 4) keterampilan dalam mengontrol diri, 5) keterampilan dalam berempati, 6) keterampilan dalam menaati aturan, dan 7) keterampilan dalam menghargai orang lain.

Berdasarkan prapenelitian dengan observasi bahwa 4 (empat) anak dari 10 (sepuluh) anak di kelas tinggi, mengalami kesulitan dalam bekerjasama. Sunarto dan Hartono (Rosita, 2013) mengungkapkan bahwa salah satu faktor yang mempengaruhi keterampilan sosial anak adalah lingkungan anak.

Interaksi sosial terbentuk karena adanya aktivitas yang dilakukan secara bersama. Dengan kata lain, interaksi sosial dengan sebaya melalui permainan tradisional sangat dibutuhkan untuk membentuk keterampilan sosial anak. Permainan tradisional engklek merupakan permainan yang paling sering dimainkan oleh anak usia SD. Oleh karena itu peneliti tertarik untuk mengkajinya secara mendalam, dengan tujuan penelitian untuk 1) mendeskripsikan permainan tradisional engklek yang dimainkan anak sekolah dasar di Desa Hamparan Perak, 2) menelaah peranan permainan tradisional engklek dalam mengembangkan keterampilan sosial anak usia sekolah dasar di desa Hamparan Perak.

\section{METODE PENELITIAN}

Penelitian ini menggunakan pendekatan kualitatif. Penelitian ini dilaksanakan di Desa Hamparan Perak dengan subjek penelitian adalah anak-anak usia sekolah dasar (6-12 tahun) di desa Hamparan Perak. 
Dalam memperoleh data yang dibutuhkan, peneliti berbaur dengan subjek, observasi, wawancara, dan dokumentasi. Data yang telah diperoleh dianalisis dengan metode berfikir ilmiah yaitu mendeskripsikan, menghubungkan, dan akan membandingkan temuan di lapangan.

\section{HASIL PENELITIAN DAN}

\section{PEMBAHASAN}

Deskripsi Permainan Engklek

- Jenis Engklek

Ada 3 bentuk engklek yang dimainkan anak di Desa Hamparan Perak, yaitu :

a. Engklek bentuk Pesawat.

b. Engklek bentuk lemari.

c. Engklek bentuk Orang.

Adapun pola atau bentuk engklek yang dimaksud adalah seperti yang tampak pada gambar 1, gambar 2, dan gambar 3 berikut:

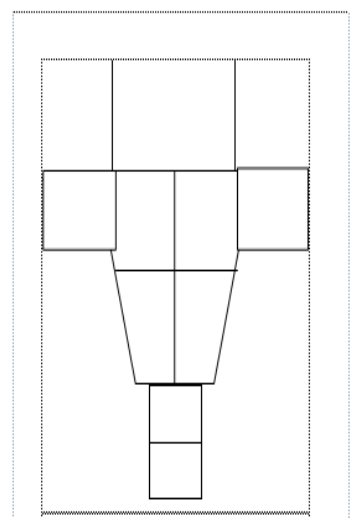

Gambar Engklek pesawat

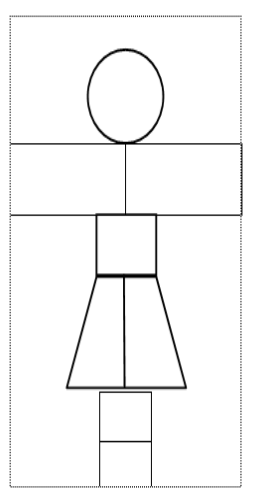

Gambar Engklek Orang

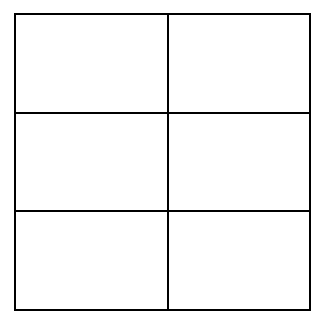

Gambar Engklek Lemari

- Alat Permainan Engklek

Membuat garis dengan kayu atau batu merah di tanah lapang sehingga berbentuk lemari, orang, dan/atau pesawat. Setiap pemain menggunakan satu gacok (benda yang berbentuk pipih) biasanya dari pecahan genting, keramik, batu, beling) untuk dilempar.

- Cara Bermain Engklek

Secara umum pemain harus melempar gacok ke satu kotak dan mengangkat satu kaki atau melompat dengan satu kaki untuk melewati kotak-kotak dalam engklek. Ada berbagai variasi dalam hal aturan 
permainan dan prosedur permainan dalam engklek ini mengingat adanya variasi pada bentuk engklek atau engkleknya yang berbeda. Berikut mekanisme aturan permainan engklek pada anak-anak di Desa Hamparan Perak:

a. Menentukan siapa yang bermain lebih dulu anakanak melakukan hompimpa.

b. Permainan dimulai dengan melempar gacok ke dalam satu kotak engklek. Tidak boleh keluar garis kotak. Bila keluar garis maka dinyatakan gugur, dan dilanjutkan dengan pemain berikutnya.

c. Kotak yang ada gacok, tidak boleh diinjak oleh pemain.

d. Pemain yang berhasil melempar gacok ke kotak, kemudian melompat dengan satu kaki dengan menekuk ke belakang kaki yang diangkat untuk melewati semua kotak yang tersedia. Setelah berhasil melalui semua kotak, pemain kemudian melompat lagi untuk mengambil gacok lalu melompat keluar kotak.

e. Kemudian pemain yang telah berhasil pada babak pertama melanjutkan permainan pada babak kedua dengan kembali melemparkan gacok ke dalam kotak kedua, dan seterusnya sampai gacok berhasil dilemparkan ke semua kotak yang tersedia.

f. Jika pemain telah berhasil melempar gacok pada semua kotak, maka tugas pemain berikutnya adalah memperoleh "rumah". Caranya, pemain harus melemparkan gacok melewati kepalanya pada salah satu kotak dengan membelakangi kotak engklek tersebut. Jika berhasil, maka pemain boleh membuat tanda rumah pada kotak yang berhasil dimasuki gacok.

g. Pemain yang memperoleh tanda rumah pada kotak engklek, boleh menginjak kotak tersebut dengan kedua kakinya.

h. Untuk selanjutnya, jika semua kotak Engklek telah diberi tanda rumah maka permainan telah selesai. Dan pemain yang memiliki paling banyak tanda rumah pada kotak Engklek dinyatakan sebagai pemenangnya.

Keterampilan Sosial Anak dalam Permainan Tradisional Engklek yaitu Anak berinteraksi dengan melakukan hompimpa untuk menentukan pemain pertama dan seterusnya. Anak bermain sesuai dengan urutan yang diperoleh dari hasil hompimpa. Ketika bermain, anak tidak ada yang 
memaksakan diri untuk bermain pertama, tapi mengikuti hasil dari hompimpa.

Anak yang melempar gacok mengenai garis atau keluar kotak, dengan suka rela anak tersebut berhenti sementara dan pemain yang lain untuk bermain. Anak yang melompat dengan menekuk satu kaki dan mengenai garis, dengan sigap pemain yang lain menegur pemain yang sedang bermain agar berhenti sementara.

Anak yang telah berhasil melempar gacok dengan membelakangi pola engklek, dapat memberi tanda rumah pada kotak sesuai dengan keinginannya sendiri. Pemain yang lain, tidak memberikan kritik atau komentar yang negatif terkait tanda rumah yang di buat pemain. Pemain yang lain menentukan tanda yang akan dibuatnya pada pola engklek dan berbeda dengan rumah yang di buat pemain lain. Pemain yang memperoleh paling banyak tanda pada pola engklek tidak memojokkan temannya yang memperoleh paling sedikit tanda. Mereka tidak berlarut dalam hasil dan melanjutkan permainan yang lain.

Anak yang baru datang ke lapangan dan memperhatikan yang sedang bermain engklek, meminta ikut bermain. Anak yang sudah main mengizinkannya ikut bermain dengan aturan anak baru tersebut bermain terakhir. Anak yang melihat temannya lagi bermain, pemain engklek menawarkan temannya yang sedang melihat tersebut agar ikut bermain.
Pemaparan kegiatan anak tersebut dalam permainan tradisional engklek, dapat dinyatakan bahwa keterampilan sosial anak berkembang. Keterampilan sosial yang dimiliki anak antara lain: kemampuan berinteraksi, bekerjasama, menyesuaikan diri, mengontrol diri, berempati, menaati aturan,dan menghargai orang lain.

\section{Pembahasan}

Nama permainan engklek di Desa Hamparan Perak sama dengan yang dideskripsikan oleh Mulyani (2013:47) dan Dharmamulya (2008:145) sedangkan Hasanah dan Pratiwi (2016:99) menyebutnya dengan Badamprak.Alat berbentuk pipih yang dilempar dalam permainan engklek, di desa Hamparan Perak disebut gacok. Permainan engklek yang dideskripsikan oleh Mulyani $(2013,47)$ dan Dharmamulya (2008:146) menggunakan istilah gacuk untuk alat yang dilempar dalam permainan engklek. Hasanah dan Hardiyanti (2016, 100) menggunakan istilah undas untuk alat yang dilempar dalam permainan engklek.

Permainan tradisional engklek di Desa Hamparan Perak lebih bervariasi. Hal itu terlihat ada 3 (tiga bentuk) dan pola engklek di Desa Hamparan Perak. Pola engklek di Desa Hamparan Perak berbeda dengan yang diungkapkan oleh Mulyani (2013:47) dan Dharmamulya (2008:147) serta Hasanah dan Hardiyanti (2016:100). Adapun pola engklek yang diungkapkan oleh 
Mulyani dan Hasanah dan Hardiyanti tersebut seperti gambar 4 berikut:

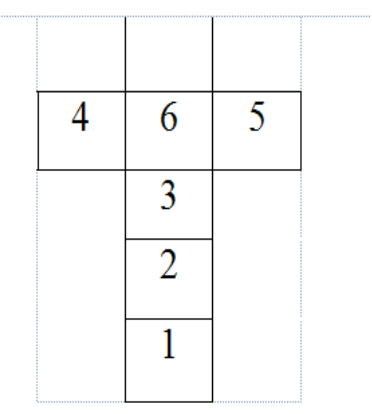

\section{Gambar Engklek Huruf T}

Cara bermain permainan tradisional engklek yang terdapat di Desa Hamparan Perak, dengan yang di ungkapkan oleh Mulyani (2013:47) dan Hasanah dan Hardiyanti (2016:101) secara umumnya sama. Permainan engklek lebih sering dimainkan oleh anak perempuan tapi kadang kala anak laki-laki juga ikut bermain. Melempar gacok ke satu kotak engklek dan melompat dengan satu kaki atau menekuk satu kaki. Bermain secara bergiliran. Pemain yang telah berhasil melalui semua kotak engklek berkesempatan untuk melempar gacok dengan membelakangi pola engklek pada satu kotak pola engklek dan bila berhasil dapat rumah pada pola engklek tersebut.

Permainan tradisional engklek yang dimainkan oleh anak usia SD di Desa Hamparan Perak memberikan dampak positif dalam perkembangan keterampilan sosial anak. Ketika anak di desa Hamparan perak bermain engklek dan menginjak garis, sontak pemain lain yang sedang memperhatikan mengatakan mati, maka pemain yang sedang bermain berhenti dan melihat yang diinjak kakinya. Dharmamulya (2008:148) juga menjelaskan bahwa apabila saat melompat anak A menginjak garis, maka anak B (pemain berikutnya) berteriak mati, maka anak A mengecek ucapan anak B. Dapat dinyatakan bahwa anak menghargai temannya yang sedang berbicara.

Adapun keterampilan sosial anak ketika bermain engklek antara lain: kemampuan berinteraksi, bekerjasama, menyesuaikan diri, mengontrol diri, berempati, menaati aturan, dan menghargai orang lain.Sejalan dengan yang diungkapkan oleh Dharmamulya (2008:25) bahwa bermain dengan permainan tradisional sebagai peningkatan kemampuan beradaptasi. Hasanah dan Hardiyanti (2016: 99) juga menjelaskan bahwa permainan tradisional engklek bermanfaat untuk perkembangan sosial emosional anak yaitu melalui permainan anak belajar bersosialisasi dengan teman sebayanya, membiasakan anak memiliki sikap kooperatif dan sportif, menghargai teman dan belajar mengendalikan emosi.

\section{SIMPULAN}

Berdasarkan hasil penelitian dan pembahasan yang telah dipaparkan sebelumnya, dapat disimpulkan bahwa:

a. Permainan tradisional engklek di Desa Hamparan Perakada 3 jenis yaitu engklek bentuk pesawat, lemari, dan bentuk orang. 
Permainan engklek ini dimainkan oleh 2 orang sampai 5 orang. Permainan ini membutuhkan lapangan, alat tulis, dan gacuk. Permainan engklek dilakukan dengan melompati setiap segi empat dari pola yang digambar dengan satu kaki dan menekuk kaki yang diangkat. Semua segi empat yang sudah dilewati oleh gacuk, pemain berkesempatan untuk membubuhi rumah di salah satu kotak, dengan cara melempar gacok ke salah satu segi empat dengan cara membelakangi pola engklek. Pemain yang memperoleh paling banyak bubuhan rumah itulah pemenangnya.

b. Permainan engklek membuat anak memiliki keterampilan sosial yaitu keterampilan dalam bekerjasama, menyesuaikan diri, berinteraksi, mengontrol diri, berempati, menaati aturan, dan menghargai orang lain.

\section{DAFTAR RUJUKAN}

DD08/ MZW. 2017. Bermain dan Bergerak untuk Fokus Belajar. Kompas. Jakarta. 11 September, hlm. 14.

Dharmamulya, S. 2008. Permainan Tradisional Jawa. Yogyakarta: Kepel Press.

Hasanah, N. I. dan Hardiyanti P. 2016. Pengembangan Anak Melalui Permainan Tradisional. Yogyakarta: Aswaja Pressindo.

Montolalu, B.E.F. dkk. 2008. Bermian dan Permainan Anak. Jakarta: Universitas Terbuka.
Mulyani, S. 2013. Permainan Tradisional Anak Indonesia. Yogyakarta: Langensari Publishing.

Prawitasari, M. 2016. Nilai-Nilai Permainan Tradisional Masyarakat Banjar. Prosiding Seminar Internasional Pendidikan Berbasis Etnopedagogi. Banjarmasin. 14 November 2015.

Rosita, I. 2013. Efektifitas Bimbingan kelompok Melalui Permainan Tradisional Untuk Meningkatkan Keterampilan Sosial Siswa. UPI: http://repository.upi.edu. Diakses: 07 Maret 2016.

Tim Playplus Indonesia. 2017. Ensiklopedia Permainan Tradisional Anak Indonesia. Jakarta: Erlangga. 